p-ISSN : 2597-8977

e-ISSN : 2597-8985

Firiyal Afifah Ahmad*)

Prodi Pendidikan IPA FMIPA Universitas Negeri Makassar

Muhammad Tawil Prodi Pendidikan IPA FMIPA Universitas Negeri Makassar

Muhammad Aqil Rusli Prodi Pendidikan IPA FMIPA Universitas Negeri Makassar

\section{PENGARUH MEDIA AUDIO VISUAL TERHADAP HASIL BELAJAR PESERTA DIDIK KELAS VIII (STUDI PADA MATERI POKOK SISTEM EKSKRESI MANUSIA)}

Abstrak: Penelitian ini bertujuan: 1) Untuk menganalisis peningkatan hasil belajar peserta didik kelas VIII SMP Negeri 1 Selayar yang diajar menggunakan media audio-visual. 2) Untuk menganalisis peningkatan hasil belajar peserta didik kelas VIII SMP Negeri 1 Selayar yang diajar menggunakan media konvensional. 3) Untuk menguji hipotesis bahwa pembelajaran menggunakan media audio-visual lebih tinggi dibandingkan dengan yang diajar menggunakan media konvensional. Jenis Penelitian ini adalah Quasi-eksperment dengan menggunakan desain penelitian Nonequivalen control group design. Populasi penelitian adalah seluruh peserta didik kelas VIII SMP Negeri 1 Selayar. Sampel dipilih dengan teknik sampling (accidental sampling) dimana pengambuilan sampel yang dilakukan secara kebetulan. Kelas yang sengaja dipilih adalah kelas VIIIi sebagai kelas eksperimen dengan jumlah peserta didik 24 orang dan kelas VIIIh sebagai kelas kontrol dengan jumlah peserta didik 26 orang. Hasil penelitian menunjukkan bahwa 1) Rata-rata peningkatan hasil belajar dengan menggunakan media audio visual terhadap peserta didik kelas VIII SMP Negeri 1 Selayar berada pada kategori tinggi dengan skor $\mathrm{N}$-Gain sebesar $0,74.2$ ) Rata-rata peningkatan hasil belajar dengan menggunakan media konvensional terhadap peserta didik kelas VIII SMP Negeri 1 Selayar berada pada kategori sedang dengan skor N-Gain sebesar 0,59.3) Hasil belajar peserta didik pada kelas VIII SMP Negeri 1 Selayar yang diajar menggunakan media audio visual lebih tinggi dibanding hasil belajar peserta didik yang diajar menggunakan media konvensional. Berdasarkan hasil analisis statistik inferensial dengan menggunakan uji-t hasil belajar peserta didik memperlihatkan $\mathrm{H}_{-} \mathrm{O}$ ditolak dan $\mathrm{H}_{-} \mathrm{a}$ diterima, artinya media audio visual berpengaruh terhadap hasil belajar. Jadi, dapat disimpulkan bahwa media audio visual dapat digunakan untuk meningkatkan hasil belajar peserta didik pada materi sistem ekskresi manusia.

Kata kunci: Media Audio Visual, Media Konvensional, Dan Hasil Belajar.

Abstract: : This study aims: 1) To analyze the increase in learning outcomes of class VIII student of SMP Negeri 1 Selayar were taught using audio-visual media. 2) To analyze the increase in learning outcomes of class VIII student of SMP Negeri 1 Selayar who were taught using conventional media. 3) To test the hypothesis that learning using audiovisual media is higher than those taught using conventional media. This type of research is Quasi eksperimen with research design Nonequivalen control grup design. The study population was all students of class VIII SMP Negeri 1 Selayar. Samples were selected by sampling technique (accidental sampling) where the sampling was done by chance. The class that was deliberately selected was class VIIIi as the experimental class
*) Correspondence Author: firiyalafifaha@gmail.com 
with 24 students and class VIIIh as the control class with 26 students. The results showed that 1) The average increase in learning outcomes by using audio-visual media for class VIII students of SMP Negeri 1 Selayar was in the high category with an $\mathrm{N}$-Gain score of 0.74 .2 ) The average increase in learning outcomes by using conventional media for class VIII students of SMP Negeri 1 Selayar is in the medium category with N-Gain score of 0,59 . 3) Learning outcomes of students in class VIII SMP Negeri 1 Selayar taught using audio-visual media higher than students learning outcomes taught using conventional media. Based on the results of inferensial statistic analysis using the $\mathrm{t}$-test on learning outcomes of students show Ho was reject and Ha was accept, meaning that audio-visual media have an effect on learning outcomes. So it can be concluded that audio-visual media can be used to improve student learning outcomes on material human excretion system.

Keyword: Audio-Visual Media, Convensional Media, And Learning Outcomes. 


\section{PENDAHULUAN}

Kegiatan belajar mengajar di kelas merupakan komunikasi tersendiri dimana guru dan siswa bertukar pikiran untuk mengembangkan ide dan pikiran. Dalam komunikasi sering timbul dan terjadi kekeliruan sehingga komunikasi tersebut tidak efektif dan efisien, antara lain disebabkan ketidaksiapan siswa untuk belajar serta kurangnya minat dan antusias. Salah satu usaha untuk mengatasi keadaan demikian adalah dengan menggunakan media dalam proses belajar mengajar, karena fungsi media dalam kegiatan tersebut di samping sebagai penyaji stimulus dalam belajar, informasi, sikap, dan juga untuk meningkatkan keserasian dalam penerimaan informasi pembelajaran (Arsyad, 2003).

Penggunaan media haruslah sejalan dengan pembaharuan di bidang kurikulum yang saat ini gencar dilakukan oleh pemerintah. Munculnya Kurikulum Berbasis Kompetensi (KBK) yang kemudian diperbarui dengan Kurikulum Tingkat Satuan Pendidikan (KTSP) dan berikutnya kurikulum 2013 (K.13) yang membutuhkan aplikasi yang tepat di dalam metode pembelajarannya, agar sesuai dengan karakteristik dan tujuan pendidikan yang termasuk di dalam kurikulum.

Pada pengamatan yang dilakukan peneliti di SMP Negeri 1 Selayar, proses pembelajaran yang berlangsung di sekolah masih berpusat pada guru, dan peserta didik berperan sebagai penerima informasi. Media yang digunakan sebagai alat bantu pembelajaran berupa media konvesional pada umumnya yaitu berupa buku cetak dan papan tulis. Menurut peserta didik kelas VIII, media tersebut dianggap kurang menarik sehingga peserta didik tidak begitu antusias dalam mengikuti pembelajaran.

Adapun hasil wawancara yang telah dilakukan peneliti dengan pendidik bahwa masalah yang dihadapi saat ini, peserta didik mengalami kesulitan dalam memahami dan mengingat materi pelajaran yang bersifat abstrak yaitu pelajaran IPA (Ilmu Pengetahuan Alam) khususnya pada materi sistem ekskresi manusia. Dimana, penggunaan media yang digunakan sebelumnya pada materi sistem ekskresi manusia berupa, buku cetak yang dibagikan, torso, maupun charta. Adapun ketercapaian KD pada materi sistem ekskresi manusia kelas VIII masih rendah. Hal tersebut dibuktikan dari nilai rata-rata ulangan semester 2017/2018 pada materi sistem ekskresi manusia yaitu 56,5 (SMP Negeri 1 Selayar).

Materi sistem ekskresi manusia merupakan materi sangat dekat dengan kehidupan seharihari dan berhubungan dengan aktivitas yang terjadi dalam diri peserta didik. Materi ini merupakan materi yang bersifat abstrak artinya sesuatu itu ada tapi tidak tampak. Dalam proses pembelajaran, peserta didik mengalami kesulitan yaitu tidak dapat mengamati secara langsung bagaimana proses-proses tersebut terjadi, selama ini pendidik lebih sering menjelaskan yang diselingi dengan memberi catatan (menggunakan metode ceramah). Di samping itu, peserta didik pun hanya menemukan beberapa gambar, tidak ada alur atau proses yang dapat diamati peserta didik dari proses ekskresi tersebut. Sehingga, hal tersebut membuat peserta didik kurang mampu memahami materi pelajaran yang disampaikan pendidik. Selain itu, peserta didik tidak memperoleh pengalaman yang mempermudah peserta didik untuk mengingat dan memahami materi yang sedang dipelajari.

Salah satu solusi dari permasalahan di atas yang dapat mendukung ketercapaian Kompotensi Dasar (KD) adalah dengan menggunakan media pembelajaran. Penggunaan media sangat berpotensi baik dalam proses belajar peserta didik dimana penggunaannya dalam proses pembelajaran sangat membantu suksesnya pembelajaran. Melalui media peserta didik dapat menggunakan indera yang dimilikinya. Menurut Bruner (Kariasi, 2016) mengungkapkan bahwa proses pembelajaran sebaiknya melibatkan semua alat indera peserta didik. Semakin banyak alat indera yang dilibatkan dalam menerima dan mengolah informasi pembelajaran, peserta didik akan semakin mudah mengerti dan mengembangkan pengetahuannya. Meskipun demikian penggunaan media di sekolah masih terbatas. 
Berdasarkan latar belakang tersebut, maka rumusan masalah pada penelitian ini dapat dirumuskan sebagai berikut:

1) Seberapa besar peningkatan hasil belajar IPA peserta didik yang diajar menggunakan media audio visual?

2) Seberapa besar peningkatan hasil belajar IPA peserta didik yang diajar menggunakan media konvensional?

3) Apakah hasil belajar IPA peserta didik yang diajar menggunakan media audio visual lebih tinggi dibandingkan dengan yang diajar menggunakan media konvensional?

\section{METODE}

Jenis penelitian ini merupakan Quasi-eksperimental yang dilakukan untuk meningkatkan hasil belajar peserta didik. Penelitian ini terdiri dari dua kelas, yaitu kelas eksperimen dan kelas kontrol. Pada kelas eksperimen diberikan pengajaran dengan menggunakan media audio visual sedangkan kelas kontrol tanpa menggunakan media audio visual (media konvensional).

Penelitian ini dilaksanakan di SMP Negeri 1 Selayar, Kabupaten Kepulauan Selayar, Provinsi Sulawesi Selatan. Waktu penelitian dilakukan pada bulan Mei, semester genap tahun 2019 selama 8 kali pertemuan. Populasi dalam penelitian ini ialah seluruh peserta didik kelas VIII SMP Negeri 1 Selayar pada tahun ajaran 2018/2019 yang terdiri dari 10 kelas dengan jumlah peserta didik keseluruhan sebanyak 252 orang. Pengambilan sampel dipilih dengan teknik accidental sampling dimana pengambilan sampel yang dilakukan secara kebetulan karena peneliti memang dengan sengaja memilih sampel tersebut pada suatu populasi. Pendidik IPA kelas VIII yang mengajar di SMP Negeri 1 Selayar menyarankan untuk mengambil kelas VIII i dan VIII h untuk dijadikan sampel karena kebetulan kelas ini belum mempelajari tentang materi sistem ekskresi manusia. Sehingga, terpilih kelas eksperimen yaitu VIII i dengan jumlah peserta didik 24 orang dan kelas kontrol yaitu VIII h dengan jumlah peserta didik 26 orang.

Penelitian ini menggunakan jenis desain sebagai berikut:

\begin{tabular}{lccccc}
\hline Kelas & & $\mathrm{O}$ & & & $\mathrm{O}$ \\
Eksperiman & 1 & & $\mathrm{X}$ & 2 & \\
Kelas Kontrol & & $\mathrm{O}$ & - & & $\mathrm{O}$ \\
& 3 & & & 4 & \\
\hline
\end{tabular}

\section{Gambar 1. Nonequivalent Control Group Design (Sugiyono, 2016)}

Instrumen penelitian yang digunakan pada penelitian ini adalah tes hasil belajar. Tes hasil belajar adalah tes yang berupa pretest dan posttest yang bertujuan untuk melihat skor yang diperoleh sebelum dan setelah penggunaan pembelajaran menggunakan media audio visual. Pemberian tes dengan menggunakan instrumen berupa soal tes objektif yang dibuat berdasarkan hasil validasi ahli. Tiap soal bernilai satu jika benar dan bernilai nol jika salah. Tes yang digunakan pada penelitian ini ialah pretset dan posttest dalam bentuk objektif sebanyak 30 item soal.

Penelitian ini menggunakan analisis deskriptif dan analisis inferensial. Analisis deskriptif bertujuan untuk mendeksripsikan tingkat hasil belajar yang diperoleh peserta didik setelah diberikan perlakuan. Analisis inferensial dilakukan untuk menguji hipotesis penelitian dan dari hasil analisis itu akan ditarik suatu kesimpulan. Sebelum diberi perlakuan, perlu dianalisis dahulu melalui uji normalitas dan uji homogenitas. 


\section{HASIL DAN PEMBAHASAN}

Hasil analisis statistik deskriptif hasil belajar IPA kelas VIII SMP Negeri 1 Selayar yang diperoleh dari skor pretest dan posttest pada kelas kontrol dan eksperimen untuk materi pokok sistem ekskresi manusia pada Tabel 1 .

Tabel 1. Statistik Data Skor Hasil Belajar Peserta Didik Kelas Eksperimen dan Kelas Kontrol

\begin{tabular}{cccccc}
\hline \multirow{2}{*}{ No. } & \multirow{2}{*}{ Statistik } & \multicolumn{2}{c}{ Kelas Eksperimen } & \multicolumn{2}{c}{ Kelas Kontrol } \\
\cline { 3 - 6 } & & Pretest & Posttest & Pretest & Posttest \\
\hline 1. & Jumlah sampel & 24 & 24 & 26 & 26 \\
2. & Skor tertinggi & 17 & 29 & 15 & 25 \\
3. & Skor terendah & 9 & 22 & 6 & 18 \\
4. & Skor rata-rata & 13,50 & 25,75 & 11,11 & 22,34 \\
5. & Standar deviasi & 2,70 & 2,30 & 2,63 & 2,12 \\
6. & Varians & 7.30 & 5,32 & 6,96 & 4,53 \\
\hline
\end{tabular}

Berdasarkan Tabel 1. Menunjukkan hasil pretest hasil belajar IPA pada kelas eksperimen yang merupakan kelas yang diberikan perlakuan, diperoleh skor rata-rata peserta didik 13,50 dengan standar deviasi 2,70. Skor tertinggi yang diperoleh 17 dan skor terendah 9 dengan skor total tertinggi yaitu 30. Dan hasil pretest hasil belajar IPA pada kelas kontrol yang merupakan kelas yang tidak diberikan perlakuan, diperoleh skor rata-rata peserta didik 11,11 dengan standar deviasi 2,63. Skor tertinggi yang diperoleh 15 dan skor terendah 6 dengan skor total tertinggi yaitu 30.

Hasil posttest hasil belajar IPA pada kelas eksperimen, diperoleh skor rata-rata peserta didik 25,75 dengan standar deviasi 2,30. Skor tertinggi yang diperoleh 29 dan skor terendah 22 dengan skor total tertinggi yaitu 30. Sedangkan hasil posttest hasil belajar IPA pada kelas kontrol, diperoleh skor rata-rata peserta didik 22,34 dengan standar deviasi 2,12. Skor tertinggi yang diperoleh 25 dan skor terendah 18 dengan skor ideal yaitu 30.

Dengan tes hasil belajar peserta didik kelas eksperimen dan kelas kontrol kemudian dikelompokkan berdasarkan kategori N-gain. Pengkategorian hasil belajar peserta didik berdasarkan skor Rerata $\mathrm{N}$-gain yang diperoleh dikedua kelas seperti pada tabel berikut:

Tabel 2. Kategori N-Gain Hasil Belajar

\begin{tabular}{ccc}
\hline Kelas & Rata-Rata Skor N-Gain & Kategori \\
\hline Eskperimen & 0,74 & Sedang \\
Kontrol & 0,59 & Sedang \\
\hline
\end{tabular}

Berdasarkan Tabel 2 menunjukkan bahwa hasil belajar peserta didik pada kelas eksperimen yang diajar menggunakan media audio visual memiliki skor $\mathrm{N}$-Gain 0,74 dengan kategori tinggi, sedangkan hasil belajar peserta didik pada kelas kontrol yang diajar menggunakan media konvensional memiliki skor N-Gain 0,59 dengan kategori sedang.

Setelah diperoleh skor pretest dan posttest dari kelas eksperimen dan kelas kontrol, selanjutnya skor $\mathrm{N}$-Gain dikategorikan lagi berdasarkan pencapaian tiap indikator seperti pada Tabel 3: 
Tabel 3. Peningkatan Pencapaian Tiap Indikator Hasil Belajar Peserta Didik Kelas Eksperimen dan Kontrol

\begin{tabular}{|c|c|c|c|c|c|}
\hline \multirow{2}{*}{ No } & \multirow{2}{*}{ Indikator } & \multicolumn{2}{|c|}{ Kelas Ekperimen } & \multicolumn{2}{|c|}{ Kelas Kontrol } \\
\hline & & $\mathrm{N}$-Gain & Kategori & N-Gain & Kategori \\
\hline 1. & $\begin{array}{l}\begin{array}{l}\text { Mengingat bagian-bagian ginjal sebagai } \\
\text { ekskresi }\end{array} \\
\text { sistem }\end{array}$ & 1 & Tinggi & 0,85 & Tinggi \\
\hline 2. & $\begin{array}{l}\text { Mengenali fungsi bagian-bagian ginjal sebagai sistem } \\
\text { ekskresi }\end{array}$ & 0,78 & Tinggi & 0,75 & Tinggi \\
\hline 3. & Menganalisis proses pembentukan urine pada ginjal & 0,61 & Sedang & 0.50 & Sedang \\
\hline 4. & Mengingat bagian-bagian kulit sebagai sistem ekskresi & 0,92 & Tinggi & 0,74 & Tinggi \\
\hline 5. & $\begin{array}{l}\text { Mengenali fungsi bagian-bagian kulit sebagai sistem } \\
\text { ekskresi }\end{array}$ & 0,72 & Tinggi & 0,62 & Sedang \\
\hline 6. & Menganalisis proses terbentuknya keringat pada kulit & 0,63 & Sedang & 0,37 & Sedang \\
\hline 7. & $\begin{array}{l}\text { Mengingat bagian-bagian paru-paru sebagai sistem } \\
\text { ekskresi }\end{array}$ & 0,95 & Tinggi & 0,80 & Tinggi \\
\hline 8. & $\begin{array}{l}\text { Mengenali fungsi bagian-bagian paru-paru sebagai } \\
\text { sistem ekskresi }\end{array}$ & 0,86 & Tinggi & 0,72 & Tinggi \\
\hline 9. & $\begin{array}{l}\text { Menganalisis proses pertukaran oksigen dengan } \\
\text { karbondioksida pada paru-paru }\end{array}$ & 0,64 & Sedang & 0,55 & Sedang \\
\hline 10. & Mengingat bagian-bagian hati sebagai sistem ekskresi & 1 & Tinggi & 0,80 & Tinggi \\
\hline 11. & $\begin{array}{l}\text { Mengenali fungsi bagian-bagian hati sebagai sistem } \\
\text { ekskresi }\end{array}$ & 0,80 & Tinggi & 0,78 & Tinggi \\
\hline 12. & $\begin{array}{l}\text { Menganalisis proses pembentukan cairan empedu } \\
\text { pada hati }\end{array}$ & 0,56 & Sedang & 0,40 & Sedang \\
\hline 13. & $\begin{array}{l}\text { Menjelaskan gangguan/ penyakit yang terjadi pada } \\
\text { organ ginjal }\end{array}$ & 0,70 & Sedang & 0,60 & Sedang \\
\hline 14. & $\begin{array}{l}\text { Menjelaskan gangguan/ penyakit yang terjadi pada } \\
\text { organ kulit }\end{array}$ & 0,72 & Tinggi & 0,57 & Sedang \\
\hline 15. & $\begin{array}{l}\text { Menjelaskan gangguan/ penyakit yang terjadi pada } \\
\text { organ paru-paru }\end{array}$ & 0,78 & Tinggi & 0,60 & Sedang \\
\hline 16. & $\begin{array}{l}\text { Menjelaskan gangguan/ penyakit yang terjadi pada } \\
\text { organ hati }\end{array}$ & 0,78 & Tinggi & 0,63 & Sedang \\
\hline 17. & $\begin{array}{l}\text { Menjelaskan gangguan/ penyakit yang terjadi pada } \\
\text { organ hati }\end{array}$ & 0,87 & Tinggi & 0,66 & Sedang \\
\hline 18. & $\begin{array}{l}\text { Menjelaskan berbagai upaya pencegahan dan cara } \\
\text { menanggulangi gangguan/penyakit pada organ kulit }\end{array}$ & 0,81 & Tinggi & 0,60 & Sedang \\
\hline 19. & $\begin{array}{l}\text { Menjelaskan berbagai upaya pencegahan dan cara } \\
\text { menanggulangi gangguan/penyakit pada organ paru- } \\
\text { paru }\end{array}$ & 0,87 & Tinggi & 0,75 & Tinggi \\
\hline 20. & $\begin{array}{l}\text { Menjelaskan berbagai upaya pencegahan dan cara } \\
\text { menanggulangi gangguan/penyakit pada organ hati }\end{array}$ & 0,75 & Tinggi & 0,80 & Tinggi \\
\hline
\end{tabular}

Berdasarkan Tabel 3. Terlihat bahwa terdapat perbedaan peningkatan indikator hasil belajar peserta didik pada kelas eksperimen. Peningkatan indikator yang paling tinggi pada kelas eksperimen adalah pada indikator ke 1, 4, 7, dan 10 dan untuk peningkatan indikator yang paling rendah pada kelas eksperimen adalah indikator ke 12 tentang menganalisis proses terbentuknya cairan empedu pada hati. Kemudian, peningkatan indikator yang paling tinggi pada kelas kontrol yaitu indikator ke 1, 7, 10, dan 20 dan untuk peningkatan indikator yang paling rendah pada kelas kontrol adalah indikator ke 6 tentang menganalisis proses terbentuknya keringat pada kulit.

Berdasarkan hasil analisis deskriptif menunjukkan bahwa hasil belajar pada kelas eksperimen berada pada kategori tinggi dan pada kelas kontrol berada pada kategori sedang. Hal 
tersebut menunjukkan bahwa media audio visual berpengaruh terhadap peningkatan hasil belajar peserta didik pada materi sistem ekskresi manusia yang memiliki konsep yang abstrak.

Melalui bantuan media audio visual, proses ekskresi yang terjadi di dalam tubuh dapat dicermati dengan nyata oleh peserta didik, selain itu media audio visual dapat memperjelas dan melengkapi informasi verbal yang diberikan, sehingga memberi kemudahan bagi peserta didik dalam menerima pelajaran yang bersifat abstrak, untuk anak usia SMP penayangan video juga mampu meningkatkan minat dan motivasi peserta didik untuk lebih aktif dalam pembelajaran, hal ini akan memberikan dampak positif terhadap peningkatan hasil belajar peserta didik.

Selain itu, seperti yang dijelaskan dalam piramida Edgar Dale, " $10 \%$ of what we read, $20 \%$ of what we hear, 30\% of what we see, 50\% of what we see and hear" (Dale, 1963). Pada piramida tersebut dapat disimpulkan bahawa penyerapan materi ketika menggunakan media audio visual sebesar 50\% karena dapat dilihat dan didengar, sedangkan jika hanya menggunakan media konvensional penyerapan materinya sebesar 30\% karna hanya melihat gambar.

Pencapaian indikator hasil belajar yang termasuk tinggi pada kelas eksperimen berada pada indikator 1, 4, 7, 8, 10, 17,19, dan pada kelas kontrol berada pada indikator 1, 2, 7, 10, 11, 19, dan 20. Kemudian, pencapaian indikator hasil belajar yang termasuk rendah pada kelas eksperimen dan kelas kontrol berada pada indikator 6 dan 12. Beberapa indikator yang termasuk tinggi pada kelas eksperimen dan kontrol merupakan indikator yang dimana peserta didik mampu untuk mengingat dan menjelaskan kembali materi pelajaran yang disampaikan berdasarkan proses pembelajaran yang telah dilakukan. Terutama pada kelas eksperimen proses pembelajaran menggunakan media audio visual sehinggah jauh lebih memudahkan peserta didik untuk mengamati dengan baik materi pelajaran.

Kemudian, indikator yang termasuk rendah pada kelas eksperimen dan kontrol merupakan indikator menganalisis (C4) proses yang terjadi pada sistem ekskresi. Pada kelas eksperimen pencapaian hasil belajar pada indikator menganalisis lebih tinggi dari pada di kelas kontrol. Penyebabnya karena beberapa peserta didik memang masih ada yang belum mampu sampai pada tahap menganalisis. Terutama pada kelas kontrol, dalam pembelajarannya media yang digunakan media konvensioanl (media gambar) yang kurang menarik perhatian dan minat belajar peserta didik. Media yang digunakan dianggap membosankan. Ini dibuktikan pada Tabel 3 data hasil peningkatan $\mathrm{N}$-gain pada tiap indikator, menunjukkan hasil yang diperoleh pada indikator menganalisis cukup rendah pada indikator 6 dan 12 yaitu 0,37 dan 0,40. Hal tersebut diperkuat berdasarkan hasil penelitian Saenab (2018), menyatakan bahwa peserta didik pada kelas kontrol yang hanya sekedar melihat gambar yang ditampilkan kurang mampu untuk menganalisis berbeda pada kelas eksperimen yang dapat melihat lebih nyata melalui video (audio visual) yang ditampilkan, hal ini memberikan gambaran bahwa penyampaian yang bersifat nyata secara audio visual dapat meningkatkan pemahaman peserta didik sehingga berpengaruh pada hasil belajarnya.

Memperkuat hasil analisis deskriptif, maka dilakukan analisis statistik inferensial untuk membuktikan hipotesis yang diajukan dengan menggunakan statistik uji-t. Sebelum digunakan ujit, terlebih dahulu di lakukan uji normalitas dan homogenitas. Uji normalitas data digunakan untuk menguji kenormalan data skor, sedangkan uji homogenitas digunakan untuk menguji data apakah homogenitas atau tidak. Data dapat dikatakan Homogen apabila $\chi^{2}$ hitung lebih kecil daripada $\chi^{2}$ tabel. Hasil uji normalitas kelas eksperimen dan kelas kontrol $\chi^{2}$ hitung lebih kecil daripada $\chi^{2}$ tabel. Data pada kedua kelas (kelas eksperimen dan kelas kontrol) dapat dikatakan homogen apabila $\chi^{2}$ hitung lebih kecil dari $\chi^{2}$ tabel. Berdasarkan hasil uji homogenitas data $\chi^{2}$ hitung lebih kecil dari pada $\chi^{2}$ tabel untuk kedua kelas (kelas eksperimen dan kelas kontrol) hal ini berarti data untuk kelas eksperimen dan kontrol terdistribusi normal.

Hasil analisis inferensial dengan menggunakan uji-t diperoleh $t_{\text {hitung }}=5,59, t_{\text {tabel }}=1,67722$. Hal ini berarti $H_{0}$ ditolak dan $H_{a}$ diterima. Sehingga dapat disimpulkan bahwa media audio visual 
berpengaruh positif terhadap peningkatan hasil belajar peserta didik kelas VIII SMP Negeri 1 Selayar pada materi sistem ekskresi manusia.

\section{KESIMPULAN}

Berdasarkan hasil penelitian dan pembahasan dapat disimpulkan sebagai berikut:

1. Rata-rata peningkatan hasil belajar dengan menggunakan media audio visual terhadap peserta didik kelas VIII SMP Negeri 1 Selayar berada pada kategori tinggi dengan skor N-Gain sebesar 0,74.

2. Rata-rata peningkatan hasil belajar dengan menggunakan media konvensional terhadap peserta didik kelas VIII SMP Negeri 1 Selayar berada pada kategori sedang dengan skor $\mathrm{N}$ Gain sebesar 0,59.

3. Hasil belajar peserta didik pada kelas VIII SMP Negeri 1 Selayar yang diajar menggunakan media audio visual lebih tinggi dibanding hasil belajar peserta didik yang diajar menggunakan media konvensional.

\section{DAFTAR PUSTAKA}

Arsyad, A. (2003). Media Pembelajaran. Jakarta: PT. Raja Grafindo Persada.

Ege, B. \& Mrio A. (2012). Pengaruh Media Audio Visual Terhadap Hasil Belajar Siswa Kelas VIII Sekolah Menengah pertama Pada Materi Sistem Peredaran Darah Manusia. Jurnal Vox Edukasi, Hal. 72-81. Vol. 3 No. 4

Fujiyanto, A. A. (2016). Penggunaan Media Audio Visual Untuk Meningkatkan Hasil Belajar Siswa Pada Materi Hubungan Antarmakhluk Hidup. Jurnal Pena Ilmiah, Vol. 1. No. 1.

Hake, R. R. (1999). Analyzing Change, Gain Score. Http://www.physich.indiana.edu/.

Jalinus, N. (2016). Media dan Sumber Pembelajaran. Jakarta: Kencana.

Kariasi, K. M. (2016). Penerapan Multimedia Model Simulasi dalam Pemebelajaran IPA Untuk Meningkatkan Aktivitas dan Hasil Belajar Siswa di Kelas VII SMP Negeri 1 Ulubongk Kabupaten Tojo Una Una. Jurnal Sains dan Teknologi Tadulako, Vol. 5. No. 3. Hal. 31-35. ISSN: 2089-8630.

Purwono, J. S. (2014). Penggunaan Media Audio-Visual Pada Materi Pelajaran Ilmu Pengetahuan Alam Di Sekolah Menengah Pertama Negeri 1 Pacitan. Jurnal Teknologi Pendidikan dan Pembelajaran, Vol. 2 No. 2 Hal. 127-144. ISSN: 2354-6441.

Rusman. (2016). Pembelajaran Tematik Terpadu Teori Praktik dan Penilaian. Jakarta: PT RajaGrafindo Persada.

Saenab, S., Ramlawati, dan Irma S. (2018). Pengaruh Media Video Dengan Pendekatan Kontektual Terhadap Hasil Belajar IPA Kelas VII MTS Negeri Gantarang Kab. Bantaeng (Pada Materi Pokok Pencemaran Lingkungan). Jurnal IPA Terpadu, Vol. 1 No. 2 Hal. 57-67.Sanjaya, W. (2010). Perencanaan dan Desain Sistem Pembelajaran. Jakarta: Prenada Media Group. 
Sanjaya, W. (2014). Media Komunikasi Pembelajaran. Jakarta: Media Prenada Group.

Sugiyono. (2016). Metode Penelitian (Pendidikan Pendekatan Kuantitatif, Kualitatif, dan R \& D). Bandung: Alfabeta.

Suprihatiningrum, J. (2016). Strategi Pembelajaran (Teori \& Aplikasi). Yogyakarta: Ar-Ruzz Media.

Tiro. (2015). Dasar-Dasar Statistika Edisi Ketiga. Makassar: Andira Publisher.

Wahyuni, T. A. (2015). Efektivitas Penggunaan Media Audiovisual pada Pembelajaran Energi dalam Sistem Kehidupan Pada Siswa SMP. Jurnal Pendidikan IPA UNNES, Hal. 998-1004. Vol. 4 No. 3 .

\section{Firiyal Afifah Ahmad}

Guru SMPN 1 Selayar, aktif melakukan penelitian pada bidang Pendidikan IPA, dapat dihubungi melalui email: firiyalafifaha@gmail.com.

\section{Muhammad Tawil}

Dosen Program Studi Pendidikan IPA FMIPA UNM, aktif melakukan penelitian pada bidang Pendidikan IPA, dapat dihubungi melalui email: muh.tawil@unm.ac.id.

\section{Muhammad Aqil Rusli}

Dosen Program Studi Pendidikan IPA FMIPA UNM, aktif melakukan penelitian pada bidang Pendidikan IPA, dapat dihubungi melalui email: m.aqilrusli@gmail.com. 